\title{
Yield, Mineral Composition, Water Relations, and Water Use Efficiency of Grafted Mini-watermelon Plants Under Deficit Irrigation
}

\author{
Youssef Rouphael, Mariateresa Cardarelli, and Giuseppe Colla ${ }^{\mathbf{1}}$ \\ Dipartimento di Geologia e Ingegneria Meccanica, Naturalistica e Idraulica \\ per il Territorio, Università della Tuscia, 01100 Viterbo, Italy
}

Elvira Rea

CRA-Centro di ricerca per lo studio delle relazioni tra pianta e suolo, 00159 Roma, Italy

Additional index words. Citrullus lanatus L., gas exchange, grafting, irrigation rate, mineral composition, water use efficiency

\begin{abstract}
Limited water supply in the Mediterranean region is a major problem in irrigated agriculture. Grafting may enhance drought resistance, plant water use efficiency, and plant growth. An experiment was conducted in two consecutive growing seasons to determine yield, plant growth, fruit quality, leaf gas exchange, water relations, macroelements content in fruits and leaves, and water use efficiency of mini-watermelon plants [Citrullus lanatus (Thunb.) Matsum. and Nakai cv. Ingrid], either ungrafted or grafted onto the commercial rootstock 'PS 1313' (Cucurbita maxima Duchesne $\times$ Cucurbita moschata Duchesne), under open field conditions. Irrigation treatments were 1.0, 0.75, and 0.5 evapotranspiration rates. In both years (2006 and 2007), marketable yield decreased linearly in response to an increase in water stress. When averaged over year and irrigation rate, the total and marketable yields were higher by $115 \%$ and $61 \%$ in grafted than in ungrafted plants, respectively. The fruit quality parameters of grafted mini-watermelons such as fruit dry matter and total soluble solids content were similar in comparison with those of ungrafted plants, whereas titratable acidity, $\mathrm{K}$, and $\mathrm{Mg}$ concentrations improved significantly. In both grafting combinations, yield water use efficiency $\left(W U E_{y}\right)$ increased under water stress conditions with higher WUE values recorded in grafted than ungrafted plants. The concentration of $\mathrm{N}, \mathrm{K}$, and $\mathrm{Mg}$ in leaves was higher by $7.4 \%, 25.6 \%$, and $38.8 \%$, respectively, in grafted than in ungrafted plants. The net assimilation of $\mathrm{CO}_{2}$, stomatal conductance, relative water content, leaf, and osmotic potential decreased under water stress conditions. The sensitivity to water stress was similar between grafted and ungrafted plants, and the higher marketable yield from grafted plants was mainly the result of an improvement in nutritional status and higher $\mathrm{CO}_{2}$ assimilation and water uptake from the soil.
\end{abstract}

Water is fast becoming an economically scarce resource in many areas of the world, especially in arid and semiarid regions such as the Mediterranean basin. The increased competition for water among agricultural, industrial, and urban consumers creates the need for continuous improvement of irrigation practices in commercial vegetable production in this region. Crop growth in arid and semiarid regions usually depends on irrigation, but inappropriate irrigation practice can result in water stress. The reduction in plant growth and yield caused by water stress has been well documented (Hartz, 1997; Jaimez et al., 1999; Kirnak et al., 2002; Ş;imşek et al., 2004). Moreover, when water supply is limited, plant structure is modified by increasing the root:shoot ratio

Received for publication 26 Nov. 2007. Accepted for publication 5 Mar. 2008.

${ }^{1}$ To whom reprint requests should be addressed; e-mail giucolla@unitus.it industry, because it results in more efficient use of irrigation water and often improves product quality (Turner, 2001).

Another way to reduce losses in production and to improve water use efficiency under drought conditions in high-yielding genotypes would be to graft them onto rootstocks capable of reducing the effect of water stress on the shoot as observed in tree crops (García-Sánchez et al., 2007; Satisha et al., 2007). In the past, grafting was used widely in vegetable crops to limit the effects of soil pathogens (Lee, 1994), but the reasons for grafting as well as the species of vegetables grafted have increased over the years. Grafts have been used to induce resistance against low (Bulder et al., 1990) and high (Rivero et al., 2003) temperatures and against iron chlorosis in calcareous soils (Romera et al., 1991) and to enhance nutrient uptake and mineral nutrition (Pulgar et al., 2000; Ruiz et al., 1997), increase synthesis of endogenous hormones (Proebsting et al., 1992), reduce uptake of persistent organic pollutants from agricultural soils (Otani and Seike, 2006), raise salt and flooding tolerance (Estań et al., 2005; Yetisir et al., 2006), and limit the negative effect of boron and copper toxicity (Edelstein et al., 2005, 2007; Rouphael et al., 2007). Nevertheless, no published data are available concerning the effects of water stress on agronomical and physiological responses of grafted mini-watermelon [Citrullus lanatus (Thunb.) Matsum. and Nakai]. Our hypothesis is that grafting may enhance drought resistance, plant water use efficiency, and plant growth. To verify this hypothesis, watermelon plants were grown in two consecutive growing seasons under full and deficit irrigation regimes. Grafted and ungrafted plants were compared in terms of yield, plant growth, fruit quality parameters, leaf gas exchange, water relations, macroelement content in fruits and leaves, and water use efficiency.

\section{Materials and Methods}

(Atkinson et al., 1999; Chaves et al., 2003). Limitation of leaf growth and an increase in stomatal resistance to gas exchanges are associated with a decrease of water and mineral nutrition flow from roots, which affects net assimilation, thereby decreasing the production and allocation of carbohydrates to the epigeous plant parts, including the fruits (Atkinson et al., 1999; Shaw et al., 2002).

In recent years, it has become clear that the maintenance of a slight water deficit can improve the partitioning of carbohydrates to reproductive structures such as fruit and also control excessive vegetative growth (Chalmers et al., 1981), carrying out what was called "regulated deficit irrigation", (RDI) by Chalmers et al. (1986). In this technique (RDI), irrigation input is removed or reduced for specific periods during the growth cycle of crops as described in eggplant (Solanum melongena L.; Kirnak et al., 2002) or watermelon (Şimşek et al., 2004). This technique is widely used in the horticultural
Experimental site and climatic data. An experiment was conducted in two consecutive growing seasons, one in 2006 (Season 1) and another in 2007 (Season 2) in an experimental station located in Viterbo, central Italy (lat. $42^{\circ} 25^{\prime} \mathrm{N}$, long. $12^{\circ} 08^{\prime} \mathrm{E}$, alt. $310 \mathrm{~m}$ above sea level). The soil was a sandy loam soil of volcanic origin (bulk density 1.1 $\mathrm{g} \cdot \mathrm{cm}^{-3}, \mathrm{pH} 7.1$, organic matter $1.8 \%$, available P $21 \mathrm{mg} \cdot \mathrm{kg}^{-1}$, exchangeable K 3380 $\mathrm{mg} \cdot \mathrm{kg}^{-1}$ with a textural analysis of $67 \%$ sand, $18 \%$ silt, and $15 \%$ clay). The measured field capacity $(-0.33$ bar) and permanent wilting point ( -15 bar) averaged $22.3 \%$ and $16.3 \%$ by weight. Table 1 summarizes the monthly climate data during the two growing seasons compared with the long-run means.

Crop management, experimental design, and irrigation treatments. In both growing seasons, watermelon plants [Citrullus lanatus (Thunb.) Matsum. and Nakai], cultivar Ingrid (Taki, Japan), which was selected as a representative mini-watermelon hybrid cultivated 
Table 1. Climatic parameters prevailed during the two growing seasons (2006 and 2007) compared with the long run data.

\begin{tabular}{|c|c|c|c|c|}
\hline Climatic parameters & May & June & July & August \\
\hline & \multicolumn{4}{|c|}{ Long run data (1984-2004) } \\
\hline Minimum air temp. $\left({ }^{\circ} \mathrm{C}\right)$ & 8.5 & 12.0 & 14.7 & 15.4 \\
\hline Maximum air temp. $\left({ }^{\circ} \mathrm{C}\right)$ & 21.1 & 25.3 & 29.3 & 29.5 \\
\hline Rainfall (mm) & 56.2 & 53.9 & 31.2 & 53.1 \\
\hline Relative humidity (\%) & 65.0 & 55.1 & 50.9 & 63.7 \\
\hline Wind speed $\left(\mathrm{m} \cdot \mathrm{s}^{-1}\right)$ & 1.1 & 1.2 & 1.2 & 1.3 \\
\hline $\mathrm{ET}_{\mathrm{o}}(\mathrm{mm})^{\mathrm{z}}$ & 130.1 & 143.8 & 169.9 & 139.2 \\
\hline Minimum air temp. $\left({ }^{\circ} \mathrm{C}\right)$ & 9.6 & 12.9 & 18.6 & 15.7 \\
\hline Maximum air temp. $\left({ }^{\circ} \mathrm{C}\right)$ & 23.7 & 27.2 & 32.3 & 27.9 \\
\hline Rainfall (mm) & 5.4 & 23.8 & 18.2 & 88.2 \\
\hline Relative humidity (\%) & 66.3 & 52.7 & 52.2 & 66.5 \\
\hline Wind speed $\left(\mathrm{m} \cdot \mathrm{s}^{-1}\right)$ & 1.1 & 1.4 & 1.4 & 1.2 \\
\hline \multicolumn{5}{|c|}{2007} \\
\hline Minimum air temp. $\left({ }^{\circ} \mathrm{C}\right)$ & 10.7 & 14.1 & 15.6 & 16.4 \\
\hline Maximum air temp. $\left({ }^{\circ} \mathrm{C}\right)$ & 23.8 & 27.7 & 31.2 & 29.0 \\
\hline Rainfall (mm) & 70.2 & 46.0 & 0.8 & 25.1 \\
\hline Relative humidity (\%) & 68.8 & 66.9 & 50.2 & 59.6 \\
\hline Wind speed $\left(\mathrm{m} \cdot \mathrm{s}^{-1}\right)$ & 1.1 & 1.1 & 1.2 & 1.3 \\
\hline $\mathrm{ET}_{\mathrm{o}}(\mathrm{mm})$ & 123.4 & 142.2 & 170.4 & 145.5 \\
\hline
\end{tabular}

${ }^{\mathrm{z}} \mathrm{ET}_{\mathrm{o}}$ reference evapotranspiration calculated according to Penman-Monteith equation.

in Italy, was used as a scion and the commercial and widely used hybrids rootstock PS 1313 (Cucurbita moschata Duchesne $\times$ Cucurbita maxima Duchesne; Petoseed Company, Parma, Italy) was used a rootstock. Seeds of the hybrid Ingrid were sowed 3 $\mathrm{d}$ before than the Cucurbita rootstock seeds to ensure uniformity in hypocotyl diameter of both the scion and rootstock. The "tongue approach" (Lee, 1994) was used for grafting the scion Ingrid onto the commercial rootstock. Grafted ('PS 1313'/'Ingrid') and ungrafted ('Ingrid') watermelon plants were transplanted on 26 May 2006 (Season 1) and on 26 May 2007 (Season 2) after a wheat crop. The 3-year rotations included wheat, watermelon, and processing tomato. In both seasons, preplant fertilizer was broadcast $\left(\mathrm{kg} \cdot \mathrm{ha}^{-1} ; 130 \mathrm{~N}-52 \mathrm{P}-141 \mathrm{~K}-12 \mathrm{Mg}\right)$ and incorporated into the soil. Additional fertilizer $\left(\mathrm{kg} \cdot \mathrm{ha}^{-1} ; 61 \mathrm{~N}-78 \mathrm{~K}\right)$ was applied through the drip system weekly for 5 weeks using $\mathrm{KNO}_{3}$ and $\mathrm{NH}_{4} \mathrm{NO}_{3}$ as sources of $\mathrm{N}$ and $\mathrm{K}$, respectively. In both growing seasons, powdery mildew, caused by the fungi Erysiphe cichoracearum and Sphaerotheca fuliginea, was controlled by two foliar treatments of penconazole (Topas 10EC; Syngenta, Milano, Italy) + dinocap (Karathane FN; Dow Agrosciences, Bologna, Italy) at the labeled rate, whereas copper-based products (Coprantol WG; Syngenta) were used twice to control downy mildew (Pseudoperonospora cubensis); aphids and spider mites were controlled with one foliar treatment of imidacloprid (Confidor 200 SL; Bayer CropScience, Milano, Italy) and two foliar treatments of fenpiroximate (Miro; Bayer CropScience), respectively. In both seasons, weeds were controlled with hand hoeing.

Treatments were defined by a factorial combination of three irrigation levels based on evapotranspiration (ET) rates $(1.0,0.75$, and 0.5 ET) and two grafting treatments (ungrafted 'Ingrid' and grafted 'PS 1313' 'Ingrid'). Each experimental unit consisted of three rows, $7 \mathrm{~m}$ in length, with 2-m row spacing and $1-\mathrm{m}$ in-row spacing containing 21 plants, giving a theoretical plant population of 5000 plants/ha. The treatments were arranged in a randomized complete block design with three replicates per treatment.

Drip lines, with in-line emitters located $0.30 \mathrm{~m}$ apart and an emitter flow rate of 3.4 $\mathrm{L} \cdot \mathrm{h}^{-1}$, were placed $10 \mathrm{~cm}$ away from the plants and were spaced with a $2-\mathrm{m}$ distance between each lateral. All treatments were given uniform optimal irrigation (1.0 ET) for 3 weeks after transplanting to promote root system establishment without water stress. The water supply was based on the actual water requirements (I), which was calculated as follows: $\mathrm{I}=\left(\mathrm{ET}_{\mathrm{o}} \times \mathrm{K}_{\mathrm{c}}\right)$ where $\mathrm{ET}_{\mathrm{o}}$ is the potential ET from micrometeorological data using the FAO Penman-Monteith method (Allen et al., 1998) and $\mathrm{K}_{\mathrm{c}}$ the crop coefficient that was estimated by the percentage groundcover by foliage development measured weekly with a digital camera pointed straight upward beneath the canopy.

Yield, fruit quality, and plant biomass measurements. In both seasons, fully mature fruits were harvest on 3 Aug. 2006 (70 d after transplanting, Season 1) and on 6 Aug. 2007 (73 d after transplanting, Season 2). Fruits that were cracked, badly misshapen, and weighed less than $1.8 \mathrm{~kg}$ were considered unmarketable. The number of fruits, mean fruit mass, and total and marketable yields were determined. The total yield and marketable yield were expressed in $\mathrm{t} \cdot \mathrm{ha}^{-1}$.

In both seasons, six representative marketable fruits per treatment were analyzed for fruit quality parameters. Immediately after harvest, fruit shape index (SI), defined as the ratio of equatorial and longitudinal lengths, was measured. From the liquid extract obtained from liquefying and filtering the mesocarp of each fruit, total soluble solids (TSS) content in juice was determined by an Atago N1 refractometer (Atago Co. Ltd., Tokyo) and expressed in ${ }^{\circ}$ Brix at $20{ }^{\circ} \mathrm{C}$.
Acidity was determined by potentiometric titration with $0.1 \mathrm{M} \mathrm{NaOH}$ up to $\mathrm{pH} 8.1$ using $15 \mathrm{~mL}$ of juice. Results were expressed as percentage malic acid in the juice. Fruits were dried in a forced-air oven at $80{ }^{\circ} \mathrm{C}$ for $72 \mathrm{~h}$ and weighed to determine the fruit dry matter (DM).

At final harvest, 70 and $73 \mathrm{~d}$ after transplanting in 2006 and 2007, respectively, seven plants per plot were separated into stems, and leaves and their tissues were dried in a forced-air oven at $80{ }^{\circ} \mathrm{C}$ for $72 \mathrm{~h}$ for biomass determination. Shoot dry biomass was equal to the sum of aerial vegetative plant parts (leaves + stems) and was expressed in $\mathrm{t} \cdot \mathrm{ha}^{-1}$.

Seasonal evapotranspiration and water use efficiency. Evapotranspiration (for each treatment) was estimated according to the water balance approach (James, 1988).

$$
\mathrm{ET}=\mathrm{I}+\mathrm{P}-\mathrm{D}_{\mathrm{r}}-\mathrm{R}_{\mathrm{f}} \pm \Delta_{\mathrm{s}}
$$

where ET is the seasonal crop ET, I is the applied irrigation water during the growth period, $\mathrm{P}$ is the effective rainfall during the growth period, $D_{r}$ is the amount of deep percolation, $R_{f}$ is the amount of runoff, and $\Delta_{\mathrm{S}}$ is the change in the soil water content determined by gravimetric sampling. All terms in Eq. (1) are expressed in millimeters. Rainfall below $5.0 \mathrm{~mm}$ was assumed to be lost by evaporation and therefore ineffective; it was treated as zero rainfall contribution.

To determine ET, soil moisture at 0 to 30 , 30 to 60 , and 60 to $90 \mathrm{~cm}$ depth was measured gravimetrically before each irrigation and at harvest. Because there was no observed runoff during the experiments and the water table was at $6 \mathrm{~m}$ depth, capillary flow to the root zone and runoff flow were assumed to be negligible in the calculation of ET. Drainage below $90 \mathrm{~cm}$, after a number of soil-water content measurements, was considered negligible. So the previous equation was reduced to $\mathrm{ET}=\mathrm{I}+\mathrm{P} \pm \Delta_{\mathrm{s}}$. Yield water use efficiency $\left(\mathrm{WUE}_{\mathrm{y}}\right.$ ) was calculated as the marketable fruit yield divided by the seasonal crop evapotranspiration (Baille, 2001), whereas biomass water use efficiency $\left(\mathrm{WUE}_{\mathrm{b}}\right)$ was calculated as the aboveground dry biomass divided by the seasonal crop evapotranspiration. $\mathrm{WUE}_{\mathrm{y}}$ and $\mathrm{WUE}_{\mathrm{b}}$ were expressed in $\mathrm{kg} \cdot \mathrm{m}^{-3}$.

Mineral analysis. For the 2006 growing season only, dried plant tissues (leaf and fruit) were ground separately in a Wiley mill (Thomas Scientific, Swedesboro, NJ) to pass through a 20 -mesh screen; then $0.5 \mathrm{~g}$ of the dried plant tissues were analyzed for the following macronutrients: $\mathrm{N}, \mathrm{P}, \mathrm{K}, \mathrm{Ca}$, and $\mathrm{Mg}$ for leaves and $\mathrm{P}, \mathrm{K}, \mathrm{Ca}$, and $\mathrm{Mg}$ for fruits. Nitrogen concentration in the leaf tissue was determined after mineralization with sulfuric acid by "Regular Kjeldahl method" (Bremner, 1965), P, K, Ca, and Mg concentrations were determined by dry ashing at $400{ }^{\circ} \mathrm{C}$ for $24 \mathrm{~h}$, dissolving the ash in $1: 25 \mathrm{HCl}$, and assaying the solution obtained using an inductively coupled plasma emission 
spectrophotometer (ICP Iris; Thermo Optek, Milano, Italy) (Karla, 1998).

Leaf gas exchange and water potential measurements. Sixty days after transplanting (for the 2006 growing season), leaf gas exchange [the net assimilation of $\mathrm{CO}_{2}$ $\left(\mathrm{ACO}_{2} ; \mu \mathrm{mol} \quad \mathrm{CO}_{2} / \mathrm{m}^{-2} \cdot \mathrm{s}^{-1}\right)$ and stomatal conductance $\left.\left(\mathrm{g}_{\mathrm{s}} ; \mathrm{mol} \cdot \mathrm{m}^{-2} \cdot \mathrm{s}^{-1}\right)\right]$ were measured using a portable photosynthetic open system (LI-6200; LI-COR, Lincoln, NE). Those measurements were made on the most recent fully expanded leaves using six replicate leaves per treatment. The LI-6200 was equipped with a well-stirred $2.5 \times 10^{-5} \mathrm{~m}^{3}$ leaf chamber with constant area inserts $(1.2 \times$ $10^{-3} \mathrm{~m}^{2}$ ) and fitted with a variable intensity red source (Model QB1205LI-670; Quantum Devices, Barneveld, WI) (Tennessen et al., 1994). Leaf temperature within the chamber was $30 \pm 2{ }^{\circ} \mathrm{C}$, vapor pressure difference between the leaf and air was $2.6 \pm 0.3{ }^{\circ} \mathrm{C}$, and $\mathrm{CO}_{2}$ concentration was $365 \pm 10 \mu \Lambda \cdot \mathrm{L}^{-1}$. All gas exchange measurements were made between 1000 and 1200 HR on clear sky days (photosynthetically active radiation greater than $1500 \mu \mathrm{mol} \cdot \mathrm{m}^{-2} \cdot \mathrm{s}^{-1}$ ).

Leaf relative water content (RWC) was measured on the fully opened fourth or fifth leaf from the top of the plant of six plants per replicate. Five leaf discs of $10 \mathrm{~mm}$ diameter were excised from the interveinal areas of each plant. For each replicate, 30 discs were pooled and their fresh weight (FW) was determined. They were floated on distilled water in petri dishes for $4 \mathrm{~h}$ in the dark to regain turgidity, and then thawed and reweighed [turgid weight (TW)]. The samples were dried at $80^{\circ} \mathrm{C}$ for $24 \mathrm{~h}$ to determine the dry weight (DW). Tests showed that complete hydration of the leaf discs occurred within $4 \mathrm{~h}$. RWC was calculated using the following formula (Jones and Turner, 1978):

$$
R W C \%=\frac{F W-D W}{T W-D W} \times 100
$$

The water potential components of leaves were measured psychrometrically using C52 sample chambers in conjunction with a HR$33 \mathrm{~T}$ Dew point microvoltmeter (Wecsor, Logan, UT) previously calibrated by a gradient series of standard $\mathrm{KCl}$ solutions on saturated discs of filter paper placed in the C52 chamber. A Peltier cooling current of $5 \mathrm{~mA}$ was applied for $15 \mathrm{~s}$, and the microvolt output was recorded with a strip chart recorder. Leaf water potential $\left(\Psi_{\mathrm{w}}\right)$ was measured between 1100 and $1400 \mathrm{HR}$ on tissue discs punched from fully expanded, healthy, and sun-exposed leaf. Leaf disc samples $(0.5$ $\mathrm{cm}$ diameter) were rapidly sealed inside the chamber in less than $8 \mathrm{~s}$. An equilibration period of 2 to $3 \mathrm{~h}$ was required to obtain stable readings of $\Psi_{\mathrm{w}}$. For osmotic potential $\left(\Psi_{\pi}\right)$, leaf discs taken from the same leaves were wrapped in aluminum foil and rapidly frozen at $-35^{\circ} \mathrm{C}$ on dry ice. When thawed, $\Psi_{\pi}$ was determined after 30 min equilibration in the same C52 sample chambers. Turgor potential $\left(\Psi_{p}\right)$ was derived as the difference between $\Psi_{\mathrm{w}}$ and $\Psi_{\pi}$.
Statistical analysis. Analysis of variance of the treatment effects on measured traits was performed using the GLM procedure of SPSS software package (SPSS 10 for Windows, 2001). Combined analysis of variance over 2 years was performed for yield, fruit yield components, aboveground dry biomass, and fruit quality [SI, DM, TSS, and titratable acidity (TA)] of mini-watermelon plants. In this analysis, year was considered a random variable. All parameters were analyzed by two-way analyses of variance within each year. In both seasons, orthogonal contrasts were used to compare irrigation rate effects (Gomez and Gomez, 1983) on selected parameters.

\section{Results}

Fruit yield and biomass production. Total yield, marketable yield, mean fruit mass, fruit number, and shoot dry biomass of watermelons were significantly influenced by irrigation rate (I) and grafting combination (G), whereas no significant differences were observed on year (Y, except for fruit mean mass), $\mathrm{Y} \times \mathrm{I}, \mathrm{Y} \times$ $\mathrm{G}, \mathrm{I} \times \mathrm{G}$, and $\mathrm{Y} \times \mathrm{I} \times \mathrm{G}$ interactions (Table 2). In 2006 and 2007, in both grafted and ungrafted plants, total yield and marketable yield decreased linearly in response to an increase in water stress (Table 2). When averaged over year and irrigation rate, the total and marketable yields were higher by $115 \%$ and $61 \%$ in grafted than in ungrafted plants, respectively. The lowest marketable yield of ungrafted plants was attributed to a reduction in both mean fruit mass and numbers of fruits per plant (Table 2).

Similar to fruit yield, the shoot dry biomass of grafted and ungrafted plants in both seasons decreased linearly in response to an increase in water stress. When averaged over year and irrigation rate, the shoot biomass was significantly higher in grafted than in ungrafted plants (Table 2).
Fruit quality. No significant differences among treatments were observed for SI, fruit DM, and TSS contents (Table 3). Moreover, the (TA was significantly affected by grafting combination but not by year, irrigation rate, or $\mathrm{Y} \times \mathrm{I} \times \mathrm{G}$ interaction (Table 3 ). When averaged over year and irrigation rate, the TA was higher in grafted than in ungrafted plants.

Concerning the fruit mineral composition, no significant difference among treatments were observed for $\mathrm{P}$ (average $1.66 \mathrm{mg} \cdot \mathrm{g}^{-1}$ dry wt) and $\mathrm{Ca}$ (average $1.90 \mathrm{mg} \cdot \mathrm{g}^{-1}$ dry wt) concentrations, whereas $\mathrm{K}$ and $\mathrm{Mg}$ concentrations were significantly affected by both irrigation rate and grafting combination with no significant irrigation $\times$ grafting interaction (Table 4). Across the grafting combination, the $\mathrm{K}$ and $\mathrm{Mg}$ concentrations increased quadratically and linearly, respectively, as the irrigation rate decreased from 1.0 to $0.5 \mathrm{ET}$. Moreover, when averaged over the irrigation rate treatments, the concentration of $\mathrm{K}$ and $\mathrm{Mg}$ in grafted plants was significantly higher by $13.0 \%$ and $23.8 \%$, respectively, than those recorded in ungrafted plants.

Seasonal evapotranspiration and water use efficiency. In both growing seasons, the seasonal ET of grafted and ungrafted plants decreased with increasing water deficit, whereas both yield and biomass water use efficiency increased under water stress conditions (Table 5). When averaged over years, the reduction in water use in ungrafted plants at $0.75 \mathrm{ET}$ and $0.5 \mathrm{ET}$ treatments was $15.1 \%$ and $32.5 \%$, respectively, compared with 1.0 $\mathrm{ET}$, whereas the reduction in water use in grafted plants at 0.75 ET and 0.5 ET treatments was $15.7 \%$, and $30.5 \%$, respectively, compared with 1.0 ET (Table 5). The WUE in grafted and ungrafted plants grown at 0.5 ET increased by $10 \%$ and $7 \%$, respectively, compared with those grown under a full irrigation regime (Table 5). Similar to $\mathrm{WUE}_{\mathrm{y}}$, the $\mathrm{WUE}_{\mathrm{b}}$ of grafted and ungrafted plants in

Table 2. Main effects of year, deficit irrigation based on evapotranspiration (ET) rates, and grafting combination on total yield $\left(\mathrm{t} \cdot \mathrm{ha}^{-1}\right)$, marketable yield $\left(\mathrm{t} \cdot \mathrm{ha}^{-1}\right)$, fruit mean mass $(\mathrm{kg} /$ fruit $)$, fruit number (no./plant), and aboveground dry biomass $\left(\mathrm{t} \cdot \mathrm{ha}^{-1}\right)$ of mini-watermelon plants.

\begin{tabular}{|c|c|c|c|c|c|}
\hline \multirow[b]{2}{*}{ Treatment } & \multicolumn{2}{|c|}{ Yield } & \multicolumn{2}{|c|}{ Marketable fruit } & \multirow[b]{2}{*}{ Dry biomass } \\
\hline & Total & $\overline{\text { Marketable }}$ & Mean mass & $\overline{\text { Number }}$ & \\
\hline \multicolumn{6}{|l|}{ Year } \\
\hline 2006 & 37.0 & 25.0 & 3.21 & 1.54 & 1.32 \\
\hline 2007 & 35.8 & 24.1 & 2.86 & 1.65 & 1.42 \\
\hline \multicolumn{6}{|l|}{ Irrigation rate } \\
\hline $1.0 \mathrm{ET}$ & 45.5 & 29.5 & 3.24 & 1.82 & 1.50 \\
\hline $0.75 \mathrm{ET}$ & 38.3 & 26.0 & 3.09 & 1.68 & 1.41 \\
\hline $0.5 \mathrm{ET}$ & 25.9 & 22.1 & 2.78 & 1.59 & 1.21 \\
\hline \multicolumn{6}{|l|}{ Graft combination } \\
\hline Ungrafted & 23.2 & 19.8 & 2.86 & 1.39 & 1.04 \\
\hline Grafted & 49.9 & 31.9 & 3.21 & 2.00 & 1.70 \\
\hline \multicolumn{6}{|l|}{ Significance $^{z}$} \\
\hline Year $(Y)$ & NS & NS & $* *$ & NS & NS \\
\hline Irrigation (I) & $\mathrm{L}^{* *}$ & $\mathrm{~L} * * *$ & $\mathrm{~L}^{* *}$ & $\mathrm{~L}^{* *}$ & $\mathrm{~L}^{* *}$ \\
\hline Graft combination $(\mathrm{G})$ & $* * *$ & $* * *$ & $* *$ & $* * *$ & $*$ \\
\hline $\mathrm{Y} \times \mathrm{I}$ & NS & NS & NS & NS & NS \\
\hline$Y \times G$ & NS & NS & NS & NS & NS \\
\hline $\mathrm{I} \times \mathrm{G}$ & NS & NS & NS & NS & NS \\
\hline $\mathrm{Y} \times \mathrm{I} \times \mathrm{G}$ & NS & NS & NS & NS & NS \\
\hline
\end{tabular}

${ }^{\mathrm{z}} \mathrm{L}=$ linear.

NS, $* * *, * * *$ Nonsignificant or significant at $P<0.05,0.01$, or 0.001 , respectively. 
Table 3. Main effects of year, deficit irrigation based on evapotranspiration (ET) rates, and grafting combination on shape index, dry matter, total soluble solids contents, and titratable acidity of miniwatermelon fruits.

\begin{tabular}{|c|c|c|c|c|}
\hline Treatment & $\begin{array}{l}\text { Shape } \\
\text { index }\end{array}$ & $\begin{array}{c}\text { Fruit dry } \\
\text { matter }(\%)\end{array}$ & $\begin{array}{l}\text { Total soluble } \\
\text { solids ( }{ }^{\circ} \text { Brix) }\end{array}$ & $\begin{array}{c}\text { Titratable } \\
\text { acidity }(\%)\end{array}$ \\
\hline \multicolumn{5}{|l|}{ Year } \\
\hline 2006 & 0.80 & 8.32 & 8.55 & 0.09 \\
\hline 2007 & 0.86 & 8.48 & 8.86 & 0.09 \\
\hline \multicolumn{5}{|l|}{ Irrigation rate } \\
\hline $1.0 \mathrm{ET}$ & 0.85 & 8.17 & 8.72 & 0.09 \\
\hline $0.75 \mathrm{ET}$ & 0.82 & 8.37 & 8.44 & 0.09 \\
\hline $0.5 \mathrm{ET}$ & 0.83 & 8.62 & 9.02 & 0.08 \\
\hline \multicolumn{5}{|l|}{ Graft combination } \\
\hline Ungrafted & 0.85 & 8.57 & 8.65 & 0.08 \\
\hline Grafted & 0.82 & 8.31 & 8.71 & 0.11 \\
\hline \multicolumn{5}{|l|}{ Significance $^{z}$} \\
\hline Year (Y) & NS & NS & NS & NS \\
\hline Irrigation (I) & NS & NS & NS & NS \\
\hline Graft combination $(\mathrm{G})$ & NS & NS & NS & $*$ \\
\hline $\mathrm{Y} \times \mathrm{I}$ & NS & NS & NS & NS \\
\hline $\mathrm{Y} \times \mathrm{G}$ & NS & NS & NS & NS \\
\hline $\mathrm{I} \times \mathrm{G}$ & NS & NS & NS & NS \\
\hline $\mathrm{Y} \times \mathrm{I} \times \mathrm{G}$ & NS & NS & NS & NS \\
\hline
\end{tabular}

${ }_{\mathrm{z} S}$, Nonsignificant or significant at $P<0.05$, respectively.

Table 4. Main effects of deficit irrigation based on evapotranspiration (ET) rates and grafting combination on macroelements content in fruit of mini-watermelons grown in 2006.

\begin{tabular}{|c|c|c|c|c|}
\hline \multirow[b]{2}{*}{ Treatment } & \multicolumn{4}{|c|}{ Mineral elements (mg.g ${ }^{-1}$ dry wt) } \\
\hline & $\mathrm{P}$ & $\mathrm{K}$ & $\mathrm{Ca}$ & $\mathrm{Mg}$ \\
\hline \multicolumn{5}{|l|}{ Irrigation rate } \\
\hline $1.0 \mathrm{ET}$ & 1.6 & 15.3 & 1.7 & 2.2 \\
\hline $0.75 \mathrm{ET}$ & 1.6 & 18.8 & 2.1 & 2.4 \\
\hline $0.5 \mathrm{ET}$ & 1.8 & 17.5 & 2.0 & 2.6 \\
\hline \multicolumn{5}{|l|}{ Graft combination } \\
\hline Ungrafted & 1.6 & 16.1 & 2.0 & 2.1 \\
\hline Grafted & 1.7 & 18.3 & 1.8 & 2.7 \\
\hline \multicolumn{5}{|l|}{ Significance $^{z}$} \\
\hline Irrigation (I) & NS & $Q^{*}$ & NS & $\mathrm{L}^{*}$ \\
\hline Graft combination $(\mathrm{G})$ & NS & $*$ & NS & $*$ \\
\hline $\mathrm{I} \times \mathrm{G}$ & NS & NS & NS & NS \\
\hline
\end{tabular}

${ }^{\mathrm{z}} \mathrm{L}=$ linear; $\mathrm{Q}=$ quadratic.

Ns, "Nonsignificant or significant at $P<0.05$, respectively.

Table 5. Effects of deficit irrigation based on evapotranspiration (ET) rates and grafting combination on evapotranspiration (ET), yield water use efficiency $\left(\mathrm{WUE}_{\mathrm{y}}\right)$, and biomass water use efficiency $\left(\mathrm{WUE}_{\mathrm{b}}\right)$ of mini-watermelon plants grown in 2006 and 2007.

\begin{tabular}{|c|c|c|c|c|c|c|c|}
\hline \multirow[b]{2}{*}{ Irrigation rate } & \multirow[b]{2}{*}{ Graft combination } & \multicolumn{2}{|c|}{$\mathrm{ET}(\mathrm{mm})$} & \multicolumn{2}{|c|}{$\mathrm{WUE}_{\mathrm{y}}\left(\mathrm{kg} \cdot \mathrm{m}^{-3}\right)$} & \multicolumn{2}{|c|}{$\mathrm{WUE}_{\mathrm{b}}\left(\mathrm{kg} \cdot \mathrm{m}^{-3}\right)$} \\
\hline & & 2006 & 2007 & 2006 & 2007 & 2006 & 2007 \\
\hline \multirow[t]{2}{*}{$1.0 \mathrm{ET}$} & Ungrafted & 238.4 & 248.3 & 9.2 & 9.5 & 0.47 & 0.49 \\
\hline & Grafted & 270.7 & 273.9 & 12.9 & 13.6 & 0.64 & 0.69 \\
\hline \multirow[t]{2}{*}{$0.75 \mathrm{ET}$} & Ungrafted & 205.7 & 207.2 & 9.3 & 9.9 & 0.50 & 0.53 \\
\hline & Grafted & 232.5 & 227.3 & 13.5 & 14.4 & 0.73 & 0.81 \\
\hline \multirow[t]{2}{*}{$0.5 \mathrm{ET}$} & Ungrafted & 162.1 & 165.9 & 9.8 & 10.5 & 0.53 & 0.55 \\
\hline & Grafted & 189.5 & 189.0 & 14.1 & 15.0 & 0.78 & 0.83 \\
\hline
\end{tabular}

both seasons increased in response to an increase in water stress.

Leaf mineral composition. The macroelements concentration in watermelon leaves as a function of the grafting combination and irrigation rate are displayed in Table 5. When averaged over grafting combination, the concentration of $\mathrm{N}, \mathrm{P}$, and $\mathrm{K}$ decreased linearly in response to an increase in water stress, whereas an opposite trend was observed for Mg concentration (Table 6). The results also indicate that the concentration of $\mathrm{N}, \mathrm{K}$, and $\mathrm{Mg}$ in leaves was significantly higher by $7.4 \%, 25.6 \%$, and $38.8 \%$, respectively, in grafted than in ungrafted plants (Table 6). Finally, no significant difference among treat- but not by the grafting combination and the irrigation $\times$ grafting interaction (Table 7 ). In both grafted and ungrafted plants, RWC, $\Psi_{\mathrm{w}}$, $\Psi_{\pi}$, and $\Psi_{\mathrm{p}}$ decreased linearly in response to an increase in water stress.

\section{Discussion}

Agronomical responses. It is well established that crop growth and yield decrease with increasing water stress (Chaves et al., 2003). Mini-watermelon marketable yield decreased with increasing water stress (Table 2 ) in agreement with many open-field studies on muskmelon (Cucumis melo L.; Fabeiro et al., 2002), eggplant (Kirnak et al., 2002), watermelon (Leskovar et al., 2004; Şimşek et al., 2004), cucumber (Cucumis sativus L.; Ertek et al., 2006), bell pepper (Capsicum annum L.; Sezen et al., 2006), and tomato (Lycopersicon esculentum L.; Topcu et al., 2007). The higher yield of mini-watermelon from grafted plants observed in this study has been reported earlier on tomato (FernándezGarcía et al., 2004) and melon (Ruiz et al., 1997; Ruiz and Romero, 1999). The lowest marketable yield recorded in ungrafted plants was associated with reduction in mean fruit mass and number of fruits per plant (Table 2). Those results are consistent with the findings of Salam et al. (2002) and Yetisir and Sari (2003) who found that grafting watermelon onto bottle gourd rootstock enhances production by increasing both mean fruit mass and number.

It was demonstrated that grafting directly affects plant yield (Neilsen and Kappel, 1996; Rivero et al., 2003) by interactions of some or all of the following processes: increase of water and nutrient uptake resulting from the vigorous root system of the rootstock (Lee, 1994; Ruiz et al., 1997), enhanced production of endogenous hormones (Zijlstra et al., 1994), or enhancement of scion vigor (Leoni et al., 1990). The joint action of some or all of these processes could explain the higher yield in mini-watermelon from grafted plants observed in the current study.

In general, water stress reduces the yield of vegetable crops, but in many cases improves their quality. In the present study, the fruit quality aspects were slightly affected by the water stress. Our results indicate that under water stress conditions, a higher concentrations of $\mathrm{K}$ and $\mathrm{Mg}$ was observed (Table 4), which is interesting from a nutritional point of view because fruits and vegetables usually contribute $35 \%$ and $24 \%$, respectively, of the total $\mathrm{K}$ and $\mathrm{Mg}$ to the dietary intake of humans (Levander, 1990). Moreover, no numerical differences were found in fruit DM and TSS contents (Table 3). Those results are consistent with the findings of Leskovar et al. (2004) who reported for diploid and triploid watermelon cultivars that increasing deficit irrigation based on ET rate did not significantly change the soluble solids content.

Many investigations have provided evidence that certain Cucurbita rootstocks may 
Table 6. Main effects of deficit irrigation based on evapotranspiration (ET) rates and grafting combination on leaf macroelements content of mini-watermelon plants grown in 2006.

\begin{tabular}{|c|c|c|c|c|c|}
\hline \multirow[b]{2}{*}{ Treatment } & \multicolumn{5}{|c|}{ Mineral elements (mg.g ${ }^{-1}$ dry wt) } \\
\hline & $\mathrm{N}$ & $\mathrm{P}$ & $\mathrm{K}$ & $\mathrm{Ca}$ & $\mathrm{Mg}$ \\
\hline \multicolumn{6}{|l|}{ Irrigation rate } \\
\hline $1.0 \mathrm{ET}$ & 34.0 & 1.2 & 13.5 & 26.4 & 5.0 \\
\hline $0.75 \mathrm{ET}$ & 32.5 & 1.1 & 12.1 & 28.1 & 5.9 \\
\hline $0.5 \mathrm{ET}$ & 30.5 & 0.9 & 11.3 & 28.0 & 6.6 \\
\hline \multicolumn{6}{|l|}{ Graft combination } \\
\hline Ungrafted & 31.2 & 1.0 & 10.9 & 27.9 & 5.07 \\
\hline Grafted & 33.5 & 1.1 & 13.7 & 27.1 & 5.40 \\
\hline \multicolumn{6}{|l|}{ Significance $^{z}$} \\
\hline Irrigation (I) & $\mathrm{L}^{* * *}$ & $\mathrm{~L}^{*}$ & $\mathrm{~L}^{* *}$ & NS & $\mathrm{L}^{* *}$ \\
\hline Graft combination (G) & $* *$ & NS & $* *$ & NS & *** \\
\hline $\mathrm{I} \times \mathrm{G}$ & NS & NS & NS & NS & NS \\
\hline
\end{tabular}

${ }^{\mathrm{z}} \mathrm{L}=$ linear.

Ns, *, **, **** Nonsignificant or significant at $P<0.05,0.01$, or 0.001 , respectively.

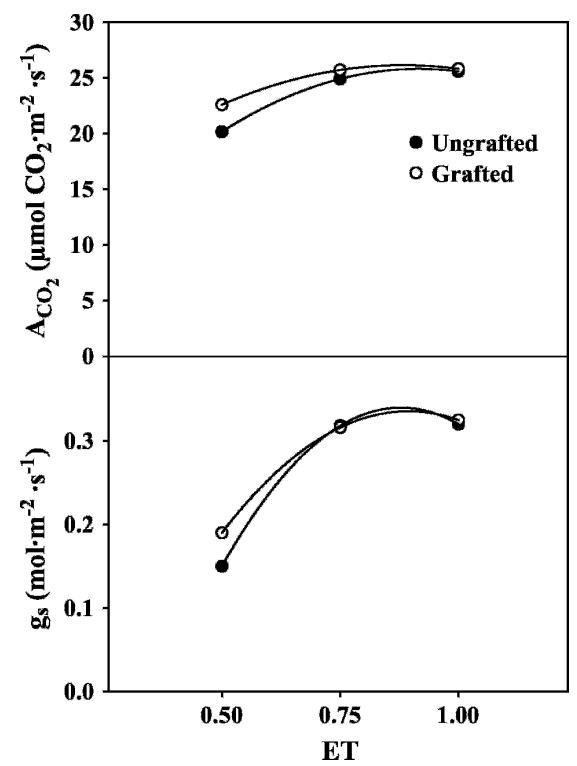

Fig. 1. Effects of deficit irrigation based on evapotranspiration $\left(\mathrm{ET}_{\mathrm{c}}\right)$ rates and grafting combination on net assimilation $\mathrm{CO}_{2}\left(\mathrm{~A}_{\mathrm{CO}_{2}}\right)$, and stomatal conductance $\left(g_{\mathrm{s}}\right)$ of mini-watermelon plants.

significantly deteriorate fruit quality (Lee, 1994; Lee and Oda, 2003). In the present study, quality characteristics such as fruit DM and TSS content of grafted mini-watermelon were similar to those of the plants grown on their own roots, whereas TA and $\mathrm{K}$ and $\mathrm{Mg}$ concentrations improved significantly. Therefore, the use of watermelons grafted onto 'PS 1313' rootstock would be a potential strategy in increasing marketable yield without detrimental effects on fruit quality.

Water use efficiency. When averaged over years, the seasonal crop ET of ungrafted and grafted mini-watermelon totaled 243 and 272 $\mathrm{mm}$, respectively (Table 5). Şimşek et al. (2004), who measured crop ET by water balance under open-field conditions, reported that total seasonal ET of 'Crimson' watermelon grown in the semiarid zone of Turkey was $647 \mathrm{~mm}$ and this value was $166 \%$ and $138 \%$ (for ungrafted and grafted plants, respectively) higher than the values recorded in this study. Explanations for this difference could be the different environments in which the plants were grown; the central region of Italy is characterized by a mild summers with maximum air temperature up to $32{ }^{\circ} \mathrm{C}$ and $\mathrm{ET}_{\mathrm{o}}$ from May to July equal to $448 \mathrm{~mm}$, whereas the Harran plain has a well-defined hot and dry season from May to September with air temperature up to $47^{\circ} \mathrm{C}$, relative humidity averaging $\approx 34 \%$, and the total class A pan evaporation from May to July equal to $1046 \mathrm{~mm}$. Another reason for this disagreement was the different watermelon cultivars used in these studies, the widely grown 'Crimson' cultivar (mean fruit weight 7 to $9 \mathrm{~kg}$ ) used by Şimşek et al. (2004), whereas the 'Ingrid' mini-watermelon is characterized by a very early maturity stage, small fruit size

Table 7. Main effects of deficit irrigation based on evapotranspiration (ET) rates and grafting combination on relative water content $(\mathrm{RWC})$, leaf water potential $\left(\Psi_{\mathrm{w}}\right)$, leaf osmotic potential $\left(\Psi_{\pi}\right)$, and leaf turgor $\left(\Psi_{\mathrm{p}}\right)$ potential of mini-watermelon plants grown in 2006.

\begin{tabular}{lcccc}
\hline Treatment & $\mathrm{RWC}(\%)$ & $\Psi_{\mathrm{w}}(\mathrm{MPa})$ & $\Psi_{\pi}(\mathrm{MPa})$ & $\Psi_{\mathrm{p}}(\mathrm{MPa})$ \\
\hline Irrigation rate & & & & \\
1.0 ET & 91.8 & -0.57 & -0.79 & 0.23 \\
$0.75 \mathrm{ET}$ & 82.6 & -0.67 & -0.86 & 0.19 \\
$\quad 0.5$ ET & 72.4 & -0.78 & -0.91 & 0.14 \\
Graft combination & & & & \\
$\quad$ Ungrafted & 80.9 & -0.67 & -0.86 & 0.18 \\
$\quad$ Grafted & 83.7 & -0.66 & -0.85 & 0.18 \\
Significance & & & & \\
$\quad$ Irrigation $(\mathrm{I})$ & $\mathrm{L}$ & $\mathrm{L}$ & $\mathrm{L}$ & $\mathrm{L}$ \\
$\quad$ Graft combination $(\mathrm{G})$ & $\mathrm{NS}$ & $\mathrm{NS}$ & $\mathrm{NS}$ & $\mathrm{NS}$ \\
I $\times$ G & $\mathrm{NS}$ & $\mathrm{NS}$ & $\mathrm{NS}$ & $\mathrm{NS}$ \\
\hline
\end{tabular}

${ }^{\mathrm{z}} \mathrm{L}=$ linear.

${ }_{\text {Ns, }, * * *, * * *}$ Nonsignificant or significant at $P<0.05,0.01$, or 0.001 , respectively.

(fruit mean weight of 3 to $4 \mathrm{~kg}$ ), and limited vegetative growth.

In this study, we found that the relationship between ET and yield was modified by water supply. As a mean of both years, the yield $W E_{y}$ of ungrafted plants amounted to $9.3,9.6$, and $10.1 \mathrm{~kg} \cdot \mathrm{m}^{-3}$ for control, moderate, and severe drought, respectively, whereas the WUE of grafted plants amounted to $13.2,13.9$, and $14.5 \mathrm{~kg} \cdot \mathrm{m}^{-3}$ for control, moderate, and severe drought, respectively (Table 5). Increased WUE values under water stress conditions were also found in eggplant (Kirnak et al., 2002), bell pepper (Dalla Costa and Gianquinto, 2002), and watermelon (Şimşek et al., 2004). The higher efficiency of water use under stress is because droughtstressed plants wilt far more than unstressed plants and wilting invariably occurs in times when the saturation deficit of the atmosphere is large. Therefore, the plant assimilates only when the saturation deficit is small and hence loses less water for every carbon molecule fixed (Bloch et al., 2006; Clover et al., 2001). Grafted plants obtained higher marketable yield in all treatments and hence used the water more efficiently than ungrafted plants.

Nutrient uptake. The low macronutrient concentration ( $\mathrm{N}, \mathrm{P}$, and $\mathrm{K}$ ) recorded in the current study under water stress conditions could be attributed to a decrease in soil moisture content in the root zone (Table 6). Those results are consistent with the findings of Simonne et al. (1998), Kirnak et al. (2001, 2002), and Kaya et al. (2003) who reported for several vegetable crops that water stress has a wider role in reducing leaf macronutrient concentrations.

The plants grafted onto 'PS 1313' showed a high capacity for $\mathrm{N}, \mathrm{K}$, and $\mathrm{Mg}$ assimilation with respect to the ungrafted ones (Table 6). In early studies, influence of rootstocks on plant nutrient uptakes was principally attributed to physical characteristics such as lateral and vertical development of roots that promoted the uptake of water and inorganic nutrients (Castle and Krezdorn, 1975). Besides, the vigorous root system of rootstocks is often capable of absorbing plant nutrients more efficiently than scion roots (Pulgar et al., 2000; Ruiz and Romero, 1999) and serves as a good supplier of endogenous hormones (Jang, 1992; Kato and Lou, 1989). This result confirms our hypothesis that grafted plants on vigorous rootstocks can improve mineral nutrition and nutrient uptake with respect to ungrafted plants.

Physiological response. Severe drought stress significantly reduced yield and biomass production of both ungrafted and grafted miniwatermelon plants. These reductions were associated with changes in various parameters of photosynthesis and leaf water status. A decline in the photosynthetic rate under water stress conditions could be attributed either to a decrease in $g_{\mathrm{S}}$ or to nonstomatal limitations (Cornic and Massacci, 1996; Jones, 1992). The parallel changes of photosynthetic rate and $g_{\mathrm{S}}$ provide evidence that the maintenance of the photosynthetic rate could be mainly attributed to the maintenance 
of $g_{\mathrm{S}}$ (Fig. 1). Moreover, decrease of soil water moisture in the root zone can lead to an osmotic adjustment (lowering of leaf $\Psi_{\pi}$ ) that is generally accepted as an important adaptation to drought. The decrease of $\Psi_{\pi}$ would compensate the drought-induced lowering of $\Psi_{\mathrm{w}}$, helping to maintain turgor pressure and cell functions under adverse water conditions (Table 7). Finally, the similar physiological responses (RWC and leaf water status) between the grafted and ungrafted watermelon plants may explain the similarity in response to drought and confirm that the higher marketable yield recorded with grafting was the result of a better nutritional status and higher $\mathrm{CO}_{2}$ assimilation and water uptake from the soil.

\section{Conclusions}

Water deficit has been shown to adversely affect yield, biomass production, leaf mineral composition, and leaf water status of watermelon, but reduced water use and increased the WUE. Our results also indicate that grafted plants exhibited higher marketable yield, improved nutritional status (higher $\mathrm{N}, \mathrm{K}$, and $\mathrm{Mg}$ concentration in leaf tissue), fruit quality parameters (higher $\mathrm{K}$ and $\mathrm{Mg}$ ), and WUE than in ungrafted plants, whereas no significant difference was observed in gas exchange and leaf water relations. Sensitivity to water stress was similar between grafted and ungrafted plants and the higher marketable yield recorded with grafting can be associated with a higher nutrient and water uptake ability of their roots and $\mathrm{CO}_{2}$ assimilation of leaves. Finally, because of the higher crop performance of watermelon plants grafted onto Cucurbita rootstock 'PS 1313', we suggest the use of grafted plants under both full and deficit irrigation regimes.

\section{Literature Cited}

Allen, R.G., L.S. Pereira, D. Raes, and M. Smith. 1998. Crop evapotranspiration: Guidelines for computing crop water requirements. FAO irrigation and drainage, Paper no. 56. Food and Agriculture Organization of the United Nations, Rome, Italy.

Atkinson, C.J., M. Policarpo, A.D. Webster, and A.M. Kuden. 1999. Drought tolerance of apple rootstocks: Production and partitioning of dry matter. Plant Soil 206:223-235.

Baille, A. 2001. Water management in soilless cultivation in relation to inside and outside climatic conditions and type of substrate. Italus Hortus 8:16-22.

Bloch, D., C.M. Hoffmann, and B. Märländer. 2006. Impact of water supply on photosynthesis, water use and carbon isotope discrimination of sugar beet genotypes. Eur. J. Agron. 24:218-225.

Bremner, J.M. 1965. Total nitrogen, p. 1149-1178. In: Black, C.A., D.D. Evans, I.L. White, L.E. Ensminger, and F.E. Clark (eds.). Methods of soil analysis. Agronomy Monograph 9, Part 2.

Bulder, H.A.M., P.R. Van Hasselt, P.J.C. Kuipe, E.J. Speek, and A.P.M. den Nijs. 1990. The effect of low root temperature in growth and lipid composition of low tolerant rootstock genotypes for cucumber. J. Plant Physiol. 138:661-666.

Castle, W.S. and A.H. Krezdorn. 1975. Effects of citrus rootstocks on root distribution and leaf mineral content of Orlando Tangelo trees. J. Amer. Soc. Hort. Sci. 100:1-4.

Chalmers, D.J., G. Burge, P.H. Jerie, and P.D. Mitchell. 1986. The mechanism of regulation of Bartlett pear fruit and vegetative growth by irrigation withholding and regulated deficit irrigation. J. Amer. Soc. Hort. Sci. 111:904907.

Chalmers, D.J., P.D. Mitchell, and L. Vanheek. 1981. Control of peach tree growth and productivity by regulated water supply, tree density and summer pruning. J. Amer. Soc. Hort. Sci. 106:307-312.

Chaves, M.M., J.P. Maroco, and J.S. Pereira. 2003. Understanding plant responses to drought from genes to whole plant. Fun. Plant Biol. 30:239264.

Clover, G.R.G., K.W. Jaggard, H.G. Smith, and S.N. Azam-Ali. 2001. The use of radiation interception and transpiration to predict the yield of healthy, droughted and virus-infected sugar beet. J. Agr. Sci. 136:169-178.

Cornic, G. and A. Massacci. 1996. Leaf photosynthesis under drought stress, p. 347-366. In: Baker, N.R. (ed.). Advances in photosynthesis: Photosynthesis and the environment. Vol. 5. Kluwer Academic Publishers, Dordrecht, The Netherlands.

Dalla Costa, L. and G. Gianquinto. 2002. Water stress and watertable depth influence yield, water use efficiency, and nitrogen recovery in bell pepper: Lysimeter studies. Aust. J. Agr. Res. 53:201-210.

Edelstein, M., M. Ben-Hu, R. Cohen, Y. Burger, and I. Ravina. 2005. Boron and salinity effects on grafted and non-grafted melon plants. Plant Soil 269:273-284.

Edelstein, M., M. Ben-Hur, and Z. Plaut. 2007. Grafted melons with fresh or effluent water tolerate excess boron. J. Amer. Soc. Hort. Sci. 132:484-491.

Ertek, A., S. Şensoy, I. Gedik, and C. Küçükyumuk. 2006. Irrigation scheduling based on pan evaporation values for cucumber (Cucumis sativus L.) grown under field conditions. Agr.Water Manag. 81:159-172.

Estań, M.T., M.M. Martinez-Rodrigue, F. PerezAlfocea, T.J. Flowers, and M.C. Boalrin. 2005. Grafting raises the salt tolerance of tomato through limiting the transport of sodium and chloride to the shoot. J. Expt. Bot. 56:703-712.

Fabeiro, C., F. Martín de Santa Olalla, and J.A. De Juan. 2002. Production of muskmelon (Cucumis melo L.) under controlled deficit irrigation in a semi-arid climate. Agr. Water Manag. 54:93-105.

Fernández-García, N., V. Martínez, A. Cerdá, and M. Carvajal. 2004. Fruit quality of grafted tomato plants grown under saline conditions. J. Hort. Sci. Biotechnol. 79:995-1001.

García-Sánchez, F., J.P. Syvertsen, V. Gimeno, P. Botia, and J.G. Perez-Perez. 2007. Responses to flooding and drought stress by two citrus rootstock seedlings with different water-use efficiency. Biol. Plant. 130:532-542.

Gomez, K.A. and A.A. Gomez. 1983. Comparison between treatment means, p. 187-240. In: Gomez, K.A. and A.A. Gomez (eds.). Statistical procedures for agricultural research. 2nd Ed. John Wiley \& Sons, New York, NY.

Hartz, T.K. 1997. Effects of drip irrigation scheduling on muskmelon yield and quality. Sci. Hort. 69:117-122.
Jaimez, R.E., F. Rada, and C. García-Núñez. 1999. The effect of irrigation frequency on water and carbon relations in three cultivars of sweet pepper (Capsicum Chinese Jacq.), in a tropical semiarid region. Sci. Hort. 81:301-308.

James, L.G. 1988. Principles of farm irrigation system design. John Wiley \& Sons Inc., New York, NY.

Jang, K.U. 1992. Utilization of sap and fruit juice of Luffa cylindrical L. Research report of Korean Ginseng and Tobacco Institute, Taejan.

Jones, H.G. 1992. Plants and microclimate: A quantitative approach to environmental plant physiology. 2nd Ed. Cambridge University Press, Cambridge, UK.

Jones, M.M. and T.C. Turner. 1978. Osmotic adjustment in leaves of sorghum on response to water deficits. Plant Physiol. 25:591-597.

Karla, Y.P. 1998. Handbook of reference methods for plant analysis. CRC Press Inc., Boca Raton, FL, p. $165-170$

Kato, T. and H. Lou. 1989. Effect of rootstocks on yield, mineral nutrition and hormonal level in xylem sap in eggplant. J. Jpn. Soc. Hort. Sci. 58:345-352.

Kaya, C., D. Higgs, H. Kirnak, and I. Tas. 2003. Mycorrhizal colonization improves fruit yield and water use efficiency in watermelon (Citrullus lanatus Thunb.) grown under wellwatered and water-stressed conditions. Plant Soil 253:287-292.

Kirnak, H., K. Cengiz, H. Davi, and G. Sinan. 2001. A long term experiment to study the role of mulches in physiology and macro-nutrition in strawberry grown under water stress. Aust. J. Agr. Res. 52:937-943.

Kirnak, H., I. Tas, C. Kaya, and D. Higgs. 2002. Effects of deficit irrigation on growth, yield, and fruit quality of eggplant under semiarid conditions. Aust. J. Agr. Res. 53:13671373

Lee, J.M. 1994. Cultivation of grafted vegetables I. Current status, grafting methods, and benefits. HortScience 29:235-239.

Lee, J.M. and M. Oda. 2003. Grafting of herbaceous vegetables and ornamental crops. Hort. Rev. (Amer. Soc. Hort. Sci.) 28:61-87.

Leoni, S., R. Grudina, M. Cadinu, B. Madedu, and M.G. Carletti. 1990. The influence of four rootstocks on some melon hybrids and a cultivar in greenhouse. Acta Hort. 28:127-134.

Leskovar, D.I., H. Bang, K.M. Crosby, N. Maness, J.A. Franco, and P. Perkins-Veazie. 2004. Lycopene, carbohydrates, ascorbic acid and yield components of diploid and triploid watermelon cultivars are affected by deficit irrigation. J. Hort. Sci. Biotechnol. 79:75-81.

Levander, O.A. 1990. Fruit and vegetable contributions to dietary mineral intake in human health and disease. HortScience 25:1486-1488.

Neilsen, G. and F. Kappel. 1996. 'Bing' sweet cherry leaf nutrition is affected by rootstock. HortScience 31:1169-1172.

Otani, T. and N. Seike. 2006. Comparative effects of rootstock and scion on dieldrin and endrin uptake by grafted cucumber (Cucumis sativus). J. Pestic. Sci. 31:316-321.

Proebsting, W.M., P. Hedden, M.J. Lewis, S.J. Croke, and L.N. Proebsting. 1992. Gibberellin concentration and transport in genetic lines of pea. Plant Physiol. 100:1354-1360.

Pulgar, G., G. Villora, D.A. Moreno, and L. Romero. 2000. Improving the mineral nutrition in grafted watermelon: Nitrogen metabolism. Biol. Plant. 43:607-609.

Rivero, R.M., J.M. Ruiz, E. Sanchez, and L. Romero. 2003. Does grafting provide tomato plants an advantage against $\mathrm{H}_{2} \mathrm{O}_{2}$ production 
under conditions of thermal shock? Physiol. Plant. 117:44-50.

Romera, F.J., E. Alcántara, and M.D. de la Guardia. 1991. Characterization of the tolerance to iron chlorosis in different peach rootstocks grown in nutrient solution. Plant Soil 130: 115-119.

Rouphael, Y., M. Cardarelli, E. Rea, and G. Colla. 2008. Grafting of cucumber as a means to minimize copper toxicity. Environ. Exp. Bot. 63:49-58.

Ruiz, J.M., A. Belakbir, A. Lopez-Cantarero, and L. Romero. 1997. Leaf-macronutrient content and yield in grafted melon plants: A model to evaluate the influence of rootstock genotype. Sci. Hort. 71:227-234.

Ruiz, J.M. and L. Romero. 1999. Nitrogen efficiency and metabolism in grafted melon plants. Sci. Hort. 81:113-123.

Salam, M.A., A.S.M.H. Masu, S.S. Chowdhury, M. Dhar, M.A. Saddeque, and M.R. Islam. 2002. Growth and yield of watermelon as influenced by grafting. J. Biol. Sci. 2:298-299.

Satisha, J., G.S. Prakash, R.M. Bhatt, and P. Sampath Kumar. 2007. Physiological mecha- nisms of water use efficiency in grape rootstocks under drought conditions. Int. J. Agr. Res. 2:159-164.

Sezen, S.M., A. Yazar, and S. Eker. 2006. Effect of drip irrigation regimes on yield and quality of field grown bell pepper. Agr. Water Manag. 81:115-131.

Shaw, B., T.H. Thomas, and D.T. Cooke. 2002. Responses of sugar beet (Beta vulgaris L.) to drought and nutrient deficiency stress. Plant Growth Regulat. 37:77-83.

Simonne, E.H., D.E. Joseph, and C.E. Harris. 1998. Effects of irrigation and nitrogen rates on foliar mineral composition of bell pepper. J. Plant Nutr. 21:2545-2555.

Şimşek, M., M. Kaçura, and T. Tonkaz. 2004. The effects of different irrigation regimes on watermelon [Citrillus lanatus (Thunb.)] yield and yield components under semi-arid climatic conditions. Aust. J. Agr. Res. 55:1149-1157.

Tennessen, D.J., E.L. Singsaas, and T.D. Sharkey. 1994. Light-emitting diodes as a light source of photosynthesis research. Photosyn. Res. 39: 85-92.
Topcu, S., C. Kirda, Y. Dasgan, H. Kaman, M. Cetin, A. Yazici, and M.A. Bacon. 2007. Yield response and $\mathrm{N}$-fertilizer recovery of tomato grown under deficit irrigation. Eur. J. Agron. 26:64-70.

Turner, N.C. 2001. Optimizing water use, p. 119 135. In: Nösberger, J., H.H. Geiger, and P.C. Struik (eds.). Crop science, progress and prospects. Third International Crop Science Congress, Hambourg. CABI, Wallingford, UK.

Yetisir, H., M.E. Çaliskan, S. Soylu, and M. Sakar. 2006. Some physiological and growth responses of watermelon [Citrullus lanatus (Thumb.) Matsum. and Nakai] grafted onto Lagenaria siceraria to flooding. Environ. Exp. Bot. 58:1-8.

Yetisir, H. and N. Sari. 2003. Effect of different rootstock on plant growth, yield and quality of watermelon. Aust. J. Exp. Agr. 43:1269-1274.

Zijlstra, S., S.P.C. Groot, and J. Jansen. 1994. Genotypic variation of rootstocks for growth and production in cucumber. Possibilities for improving the root system by plant breeding. Sci. Hort. 56:195-196. 